\title{
THE EFFECTS OF COMMUNICATION, WORK ENVIRONMENT AND WORK DISCIPLINE ON THE PERFORMANCE OF VILLAGE OFFICERS IN KROYA SUB-DISTRICT CILACAP REGENCY
}

\author{
Hermin Endratno ${ }^{1}$, Fahmi Afrizal ${ }^{2}$ \\ ${ }^{1} \mathrm{~A}$ student of doctoral program of Universitas Jenderal Soedirman \\ ${ }^{2}$ A graduate of FEB, Universitas Muhammadiyah Purwokerto \\ herminendratno@ump.ac.id
}

\begin{abstract}
The purpose of this study is to examine the effect of communication, work environment and work discipline on the performance of village officers in Kroya District, Cilacap Regency. The sampling technique in this study was done by purposive sampling method. Multiple regression analysis was used to analyze the data. The results of the analysis indicate that the variables of communication, work environment and work discipline significantly affect the performance of village officers in the Kroya Sub-district, Cilacap Regency.
\end{abstract}

Keywords: Communication, Work Environment, Work Discipline, Performance

\begin{abstract}
ABSTRAK
Tujuan penelitian ini adalah untuk menguji pengaruh komunikasi, lingkungan kerja dan disiplin kerja terhadap kinerja pegawai balai desa di Kecamatan Kroya Kabupaten Cilacap. Penelitian ini menggunakan metode purposive sampling. Alat analisis yang digunakan adalah analisis regresi berganda. Hasil analisis menunjukan bahwa variabel komunikasi, lingkungan kerja dan disiplin kerja berpengaruh signifikan terhadap kinerja pegawai desa di Kecamatan Kroya cilacap
\end{abstract}

Kata kunci: Komunikasi, Lingkungan Kerja, Disiplin Kerja, Kinerja

\section{INTRODUCTION}

Human resource is an important factor in the survival of an organization. Good employee performance will greatly support the achievement of organizational goals. The same goes for village officers in Kroya Sub-District, Cilacap Regency. Hence, when the organization can provide support both through good communication, work discipline and adequate work environment for officers, the officers can surely provide good performance.

Good communication can lead to harmony among employees, either communication between the leader and employees or between the officers and fellow officers. According to Harun
(2008) communication is originated from the Latin language namely communicatus which means "sharing" or "being shared". Therefore, communication is an effort aimed at sharing to achieve togetherness. With good communication, employee performance is expected to be in order to achieve institutional goals. Susanto (2013), Wardhani. (2016), Srimiatun and Prihatinta (2017) found that communication has a significant effect on employee performance. This is different from Sumaki (2015) who found that communication has an effect on employee performance although it not a significant effect. 
Work environment is also another factor that needs to be considered by institutions. A comfortable, safe working environment will support employees in carrying out their duties more efficiently. This can have a positive influence on the psychological condition of employees in achieving performance. According to Nitisemito (2008) the work environment is anything that exists around the worker and that can affect him in carrying out the tasks that are charged. Iskandar (2017), Taufiq et al (2012), Peoni. (2014) Gunaseelan (2014), Prasetya et al. (2014), Wardhani. (2016), that the work environment has a significant and significant effect on employee performance.

In addition to the work environment, work discipline is also important in supporting the achievement of organizational goals. According to Rivai (2011), work discipline is a means used by leaders to communicate with employees so that they are willing to change a behavior and as an effort to increase awareness and willingness of a person to meet all company regulations. The study of Suci and Idrus (2015), Mangkunegara and Waris (2015), Thaief et al (2015) found that work discipline affects on performance. This is different from the findings of Parerung et al
(2014) who state that work discipline does not significantly influence performance.

This study intends to combine several variables from previous studies, namely communication, work environment and work discipline variables. The formulation of the problem raised is whether or not communication, work environment and work discipline affect performance.

\section{RESEARCH METHOD}

This is a quantitative research. Quantitative research is a process of finding knowledge that uses data in the form of numbers as a means of analyzing information about what needs to be identified (Kasiram 2008). The population in this study were 310 village officers in Kroya Sub-district, Cilacap Regency. The sample in this study was that part of the village employees selected as respondents as many as 103 people. Purposive sampling method is used as the sampling technique in this study with criteria. It obtained the officiers with the minimum service life of 1 year. The type of data in this study is primary data sourced from respondents' answers to statements shared by researcher. Questionnaire was used to collect the data of this research.

Table 1. Operational Definition

\begin{tabular}{|l|l|}
\hline \multicolumn{1}{|c|}{ Variable } & \multicolumn{1}{c|}{ Indicator } \\
\hline $\begin{array}{l}\text { Communication } \\
\begin{array}{l}\text { Communication in this study is the link } \\
\text { of communication either among } \\
\text { employees or with leader(s) }\end{array}\end{array}$ & $\begin{array}{l}\text { The element of communication according to } \\
\text { Marwansyah (2010): } \\
\text { a. Good relationships among employees } \\
\text { b. Nature of mutual respect between } \\
\text { employees and leaders }\end{array}$ \\
& $\begin{array}{l}\text { c. Emotion, mood of trust feeling among } \\
\text { employees }\end{array}$ \\
\hline $\begin{array}{l}\text { Work environment } \\
\begin{array}{l}\text { The work environment in this study is } \\
\text { the overall state of the work area and } \\
\text { facilities that support the work of village } \\
\text { officiers. }\end{array}\end{array}$ & $\begin{array}{l}\text { Work environment indicators according to } \\
\text { 1. Lights }\end{array}$ \\
\hline
\end{tabular}




\begin{tabular}{|c|c|}
\hline & $\begin{array}{l}\text { 4. Comfort of the workplace } \\
\text { 5. Employee relations }\end{array}$ \\
\hline $\begin{array}{l}\text { Work discipline } \\
\text { The work discipline in this study is the } \\
\text { awareness of employees / officiers in } \\
\text { complying with applicable regulations at } \\
\text { the village office }\end{array}$ & $\begin{array}{l}\text { According to Hasibuan (2002), there are } \\
\text { indicators of work discipline: } \\
\text { 1. Purpose and ability } \\
\text { 2. Leadership Model } \\
\text { 3. Logrolling } \\
\text { 4. Justice } \\
\text { 5. Waskat (supervision attached) } \\
\text { 6. Penalty sanctions } \\
\text { 7. Assertiveness } \\
\text { 8. Human relations }\end{array}$ \\
\hline $\begin{array}{l}\text { The performance } \\
\text { Performance in this study is the result of } \\
\text { work achieved by someone based on job } \\
\text { requirements". }\end{array}$ & $\begin{array}{l}\text { According to Bangun (2012) performance } \\
\text { indicators are: } \\
\text { Amount of work } \\
\text { Amount of work is all work that is charged } \\
\text { to employees. } \\
\text { Quality of work } \\
\text { Quality of work is the good or bad work that } \\
\text { has been completed. } \\
\text { Accuracy } \\
\text { Completion of work assigned to employees. } \\
\text { Presence } \\
\text { Attendance is a presence that shows whether } \\
\text { or not an employee is consistent. } \\
\text { Cooperative ability. }\end{array}$ \\
\hline
\end{tabular}

\section{A. Research Intrument}

According to Sujarweni (2015) data collection instruments are selected and used in collecting data so that these activities become systematic and simple. Likert scale approach is used in this study. According to Sujarweni (2015) Likert scale is used to measure the attitudes, opinions and perceptions of a person or group of people about social phenomena. Each item has five alternative answers including the following:

Strongly Agree (SS) $\quad=5$

Agree (S) $\quad=4$

Neutral $(\mathrm{N}) \quad=3$

Disagree (TS) $\quad=2$

Strongly Disagree $(\mathrm{STS})=1$

\section{B. Quality Test Data}
1. Validity Test

According to Sujarweni (2015) the validity test is used to measure the validity of a questionnaire. A questionnaire can be said to be valid if it is able to express something measured by the questionnaire. According to Sujarweni, the validity test uses the product moment correlation technique by testing each question item in the questionnaire. In the validity test the significance is analyzed by comparing the value of $\mathrm{r}$ count with $\mathrm{r}$ table $(\mathrm{df}=\mathrm{n}-\mathrm{k})$. The validity criteria for each item in the questionnaire are as follows:

a. Statement items are declared valid if $r$ count $>r$ table.

b. Statement items are declared invalid if $r$ count $<r$ table.

2. Reliability test 
According to Sujarweni (2015) the reliability test is used to test the extent to which a measurement can be trusted. According to Ghozali (2001) a questionnaire is said to be reliable if a person's answer to a statement is consistent or stable over time. A variable is said to be reliable if it has cronbach alpha $>0.60$. While the variable is said to be unreliable if it has a Cronbach alpha $<0.60$.

\section{Classic Assumption Test}

1. Normality Test

According to Suliyanto (2011) normality test is used to test whether the standardized residual values in the regression model are normally distributed or not. The residual value is said to have normal distribution if the standardized residual value is mostly close to the average value. If the data are not normally distributed then they cannot continue the research. Kolmogorov-Smirnov (K-S) analysis is used in this study. Kolmogorov-Smirnov (K-S) is a normality test using the cumulative distribution function. Standardized residual values are normally distributed if $\mathrm{K}$ count $<\mathrm{K}$ table or sig value. $>\alpha$.

2. Multicollinearity Test According to Sujarweni (2015) Multicollinearity Test is used to determine whether there are independent variables with similarities among the independent variables in a model. In a good regression model there should be no correlation among independent variables. Multicollinearity test can be done using TOL (tolerance) and VIF (Variance Inflation Factor). The multicollinear symptoms occurs if the VIF value $>10$ and the TOL value $<0.10$ while if the VIF value
$<10$ and the TOL value $>0.10$ then the symptoms of multicollinearity do not occur.

3. Heteroscedasticity Test

According to Sujarweni (2015) heteroscedasticity test is used to test the occurrence of differences in residual variance from one observation period to another. According to Suliyanto (2011), how to predict the presence or absence of heteroscedasticity in a model can be seen using the Glejser test. If the significance value of the significance of each independent variable $>0.05$ then there are no symptoms of heteroscedasticity and vice versa.

\section{Hypothesis Test}

1. Multiple Linear Regression Analysis

Regression analysis is used to determine the effect of communication, work environment and work discipline on employee performance with the following model $Y=a+\beta_{1} X_{1}+\beta_{2} X_{2}+\beta_{3} X_{3}+$ $\beta_{4} \mathrm{X}_{4}+\mathrm{e}$

Description:

$\mathrm{X}_{1} \quad=$ communication

$\mathrm{X}_{2} \quad=$ work environment

$\mathrm{X}_{3} \quad=$ work discipline

$\mathrm{Y} \quad=$ employee performance

a $\quad=$ a Constant

$\beta_{1}-\beta_{4}=$ Multiple Linear

Regression Coefficient

e $\quad=$ Residual/Error

2. Hypothesis Test (Uji T)

According Suliyanto (2011)

$T$ test is used to test whether the variable significantly affects the dependent variable or not. A variable will have a significant effect if the $t$ count variable is greater than the value of t table (df:, $\mathrm{n}-\mathrm{k}$ or $(0.05, \mathrm{n}-\mathrm{k}))$. To calculate the value of tcount, the following formula is used: 


$$
\mathrm{t}=\frac{\mathrm{bj}}{\mathrm{Sbj}}
$$

Descriptiom :

$\mathrm{t}=$ Tcount value

$\mathrm{bj}=$ Regression coefficient

$\mathrm{sbj}=$ Standard error of the

regression coefficient
If sig. $>0.05$ or $-\mathrm{t}$ table $<\mathrm{t}$ count $<\mathrm{t}$ table then the independent variable affects the dependent variable. Conversely if sig. $<0.05$ or if $\mathrm{t}$ count <- $\mathrm{t}$ table or $\mathrm{t}$ count $>\mathrm{t}$ table, then the independent variable has no effect on the dependent variable.

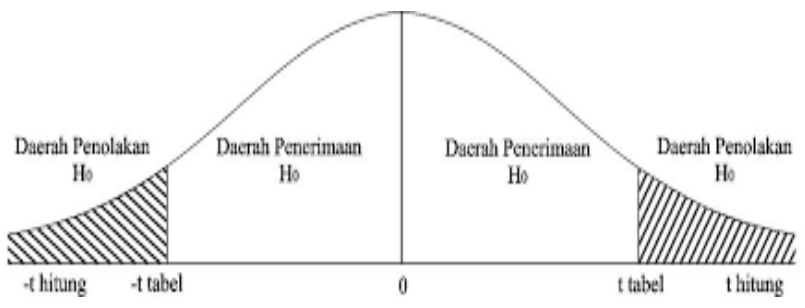

Figure 1. T test Curve

3. Goodness of Fit Test

a. F Test

According to Suliyanto (2011) the calculated $F$ value is used to test goodness of fit, whether the equation model formed belongs to the fit criteria or not. The F test is also used to test whether the free variable used in the model is able to explain changes in the value of dependent variables or not. To conclude whether the model is fit or not, the calculated $F$ value and the table $F$ value must be compared with df: (k-1), (n-1). To calculate the magnitude of the calculated $F$ value, the following formula is used:

$$
\mathrm{F}=\frac{R^{2} /(k-1)}{1-R^{2} /(n-1)}
$$

Information:

$\mathrm{F}=\mathrm{F}$ count value

$\mathrm{R} 2=$ coefficient of determination

$\mathrm{k}=$ Number of variables

$\mathrm{n}=$ Number of observations (sample size)

If $\mathrm{F}$ countc $>\mathrm{F}$ table, then it can be concluded that the regression equation model formed is in fit criteria. Conversely, if $\mathrm{F}$ count $<\mathrm{F}$ table, then the criteria do not match.

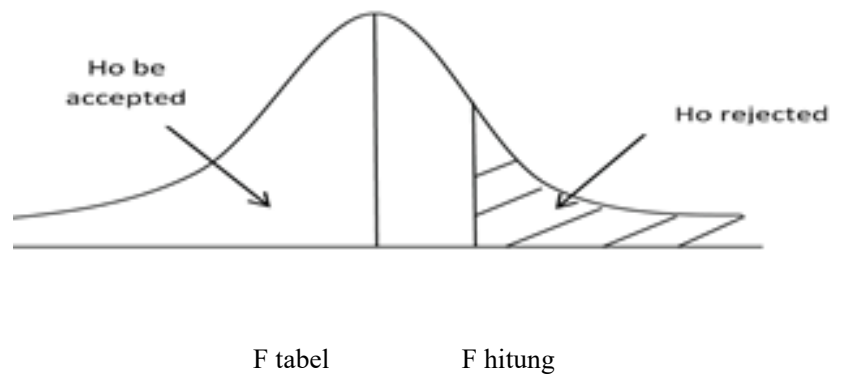

Figure 2. Fcount Curve 
b. Determination Coefficient Test $\left(R^{2}\right)$

According to Sujarweni
(2015) the determination
coefficient $\left(\boldsymbol{R}^{2}\right)$ is used to
determine the percentage change
in the dependent variable (Y)
caused by the independent
variable (X). If $\boldsymbol{R}^{2}$ gets bigger,
then the percentage change in
the dependent variable (Y)
caused by the independent
variable (X) is getting higher. If
$\boldsymbol{R}^{2}$ gets smaller, then the
percentage change in the
dependent variable (Y) caused
by the independent variable (X)
is getting lower.

\section{RESULTS AND DISCUSSIONS}

A. Validity Test

A total of 103 questionnaires were returned and analyzed. Based on the results of the validity test, it is found that all statement items in this study are valid (Pearson correlation values indicate sig $<0.05)$.

\section{B. Reliability Test}

The reliability test of a variable or construct of a research data can be seen from the results of the Cronbach Alpha statistical test $(\alpha)$. A variable or construct is said to be reliable if the Cronbach Alpha value $>0.7$. The more the alpah value is the more reliable the data value is. The results of reliability testing can be seen in Table 2 below:

Table 2. Reliability Test Results

\begin{tabular}{|l|l|l|l|}
\hline Variable & $\begin{array}{l}\text { Cronbach's } \\
\text { Alpha Value }\end{array}$ & $\begin{array}{l}\text { Value of R } \\
\text { table }\end{array}$ & Note \\
\hline Communication &, 755 & 0,195 & Reliable \\
\hline Work environment &, 681 & 0,195 & Reliable \\
\hline Discipline &, 770 & 0,195 & Reliable \\
\hline Performance &, 651 & 0,195 & Reliable \\
\hline
\end{tabular}

Based on the above table, it is known that the value of $r$ count is more than $r$ table so it can be concluded that the questionnaire can be said to be reliable so that henceforth the items in each variable concept are feasible to be used as a measurement tool.

\section{Classical assumption test}

All data in this study have passed the classical assumption test.

\section{Feasibility Test Model (F Test)}

The $\mathrm{F}$ test is also used to test whether the independent variable used in the model is able to explain the change in the value of the dependent variable or not.

Table 3. Results of F test analysis

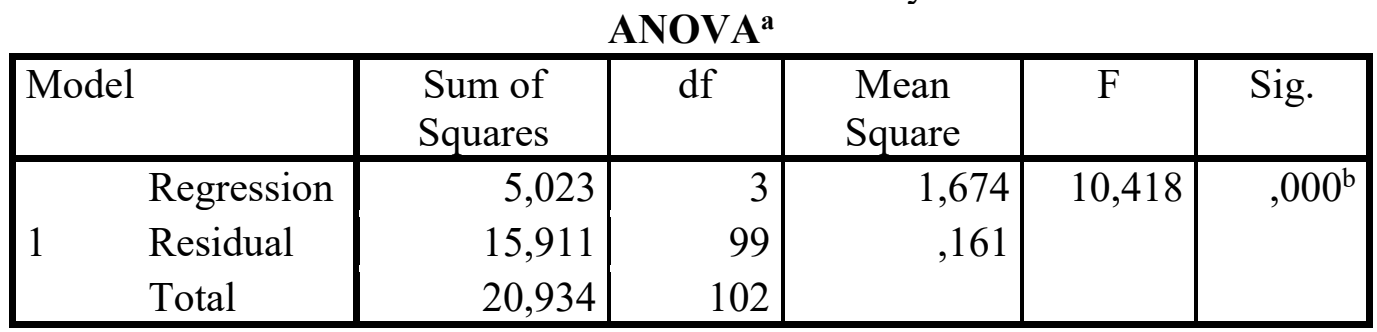

a. Dependent Variable: Average_Performance of Employees 
b. Predictors: (Constant), Average _ Work Discipline, Average_Communication, Average _Work Environment

Based on Table 3, it is known that the calculated $\mathrm{F}$ value is 10.418 and the $\mathrm{F}$ table value is 2.696. Thus, the regression model is declared fit because the calculated $F$ value is greater than the value of the $f$ table.
Multiple regression analysis is used to analyze the effect of several independent variables on the dependent variable.

\section{E. Multiple Regression Analysis}

Table 4. Results of Multiple Linear Regression Analysis

\section{Coefficients $^{\text {a }}$}

\begin{tabular}{|c|c|c|c|c|c|}
\hline \multirow[t]{2}{*}{ Model } & \multicolumn{2}{|c|}{$\begin{array}{c}\text { Unstandardized } \\
\text { Coefficients }\end{array}$} & $\begin{array}{l}\text { Standardized } \\
\text { Coefficients }\end{array}$ & \multirow[t]{2}{*}{$\mathrm{t}$} & \multirow[t]{2}{*}{ Sig. } \\
\hline & B & Std. Error & Beta & & \\
\hline (Constant) & 2,372 & ,503 & & 4,714 & ,000 \\
\hline $\begin{array}{l}\text { Average- } \\
\text { Communication }\end{array}$ & 224 & , 105 & ,218 & 2,132 & , 035 \\
\hline $\begin{array}{l}\text { Average_Work } \\
\text { Environment }\end{array}$ & - 250 & ,082 & ,312 & 3,031 & - 003 \\
\hline $\begin{array}{l}\text { Average_Work } \\
\text { Discipline }\end{array}$ &,- 103 & ,080 &,- 113 & $-1,286$ & 201 \\
\hline
\end{tabular}

a. Dependent Variable: average_employee performance

Based on the data in table 4, the following regression equation can be made:

$\hat{Y}=\alpha+\beta_{1} X_{1}+\beta_{2} X_{2}+\beta_{3} X_{3}+\varepsilon$

$\left.\mathrm{Y}=2,237+0,224 \mathrm{X}_{1}+0,250 \mathrm{X}_{2}\right)+(-$ $0,103) \mathrm{X}_{3}$

$\mathrm{Y}$ is employee performance,

$\mathrm{X} 1$ is communication, $\mathrm{X} 2$ is extrinsic motivation and $\mathrm{X} 3$ is work environment. So the regression equation can be explained as follows: $\alpha=2.237$ indicates a constant with positive value or can be explained if communication, and the work environment, work discipline is zero, the employee's performance is 2.237 units.

$\beta 1=0.224$ means that if communication increases by one unit, employee performance increases by
0.224 units assuming other variables are fixed.

$\beta 2=0,250$ means that if the work environment increases by one unit, employee performance increases by 0,250 units assuming other variables are fixed.

$\beta 3=-0.103$ means that if discipline decreases by one unit, employee performance decreases by 0.103 units assuming other variables remain.

\section{F. T test}

$\mathrm{T}$ test is used to test whether the variable significantly influences the dependent variable or not. A variable will have a significant effect if the count value of $t$ variable is greater than the value of $t$ table. 
Table 5. T test results

Coefficients $^{\mathrm{a}}$

\begin{tabular}{|c|c|c|c|c|c|c|}
\hline \multirow{2}{*}{\multicolumn{2}{|c|}{ Model }} & \multicolumn{2}{|c|}{$\begin{array}{l}\text { Unstandardized } \\
\text { Coefficients }\end{array}$} & $\begin{array}{l}\text { Standardized } \\
\text { Coefficients } \\
\end{array}$ & \multirow[t]{2}{*}{$\mathrm{t}$} & \multirow[t]{2}{*}{ Sig. } \\
\hline & & B & Std. Error & Beta & & \\
\hline \multirow{4}{*}{1} & (Constant) & 2,372 & ,503 & & 4,714 &, 000 \\
\hline & $\begin{array}{l}\text { Average- } \\
\text { Communication }\end{array}$ & ,224 & ,105 & 218, & 2,132 & ,035 \\
\hline & $\begin{array}{l}\text { Average_Work } \\
\text { Environment }\end{array}$ &, 250 &, 082 & ,312 & 3,031 &, 003 \\
\hline & $\begin{array}{l}\text { Average_Work } \\
\text { Discipline }\end{array}$ &,- 103 &, 080 &,- 113 & $-1,286$ & ,201 \\
\hline
\end{tabular}

\section{G. Discussion}

1. The Effect of Communication on Employee Performance

Based on the results of the $t$ test analysis, it is known that the $t$ value is 2.132 (greater than $\mathrm{t}$ table (1.984)) and the significance level is 0.030 (smaller than 0.05). This means that there is an effect of the communication variables on the performance of the officers in Village offices in Kroya Subdistrict.

This result is in line with previous research by Puspita et al (2016) stating that communication has a positive and significant effect on employee performance.

2. The Effect of Work Environment on Employee Performance

Based on the results of the $t$ test analysis, the $\mathrm{t}$ value is 3.031 (greater than $t$ table (1.984)) and the significance level is 0.003 (less than 0.05). This means that there is an effect of the work environment variables on employee performance at the village offices in Kroya Subdistrict.

This result is in line with previous research by Setiawan (2013) stating that the work environment has a positive and significant effect on employee performance.

3. The Effect of Work Discipline on Employee Performance

Based on the results of the $t$ test analysis, the $\mathrm{t}$ value is -1.286 (greater than the t-table value (1.984)) and the significance level is 0.201 (greater than 0.05), meaning that there is a negative effect of work discipline on employee performance at the village offices in Kroya Subdistrict.

This result is in line with previous studies by Suci and Idrus (2015), Mangkunegara and Waris (2015) Thaief et al (2015) stating that work discipline affects the employee performance.

\section{The coefficient of determination}

The coefficient of determination is notated by essentially measuring how far the ability of the model in explaining the variation of dependent variables. The value of the coefficient of determination is between zero and one. A small value means the ability of the dependent variables is very limited. Value that is close to one 
means the independent variables providing almost all the information the dependent variable (Ghozali, are needed to predict variations in 2016).

Table 6 . The Results of the coefficient of determination

Model Summary

\begin{tabular}{|l|r|r|r|r|}
\hline $\begin{array}{l}\text { Mode } \\
1\end{array}$ & R & R Square & $\begin{array}{c}\text { Adjusted R } \\
\text { Square }\end{array}$ & $\begin{array}{c}\text { Std. Error of } \\
\text { the Estimate }\end{array}$ \\
\hline 1 &, $490^{\mathrm{a}}$ &, 240 &, 217 &, 40090 \\
\hline
\end{tabular}

a. Predictors: (Constant), average_work discipline, average_communication, average _work environment

Based on the data in table 6, it can be seen that the Adjusted R2 value is $0.217(21.7 \%)$. This means that employee performance variables that can be explained by communication, work environment and work discipline variables are $21.7 \%$ while the remaining $78.3 \%$ of other variables cannot be explained in this study.

\section{H. Implications}

1. The village head is advised to increase the relationship or communication among employees.

2. Sense of mutual assistance employees in completing work needs to be improved.

3. Comfort at work needs to be improved

4. Regulations related to discipline and leader model need to be maintained

\section{CONCLUSION}

Based on research and data analysis that has been done, it can be concluded:

A. Communication affects employee performance at village offices in Kroya Subdistrict.

B. The work environment affects the employees' performnce at village offices in Kroya Subdistrict.

C. Work discipline has a negative effect on employees' performance at village offices in Kroya Subdistrict.

The limitation of this study is that the value of Adjusted $\boldsymbol{R}^{2}$ is low, only 0.217 or only $21.7 \%$. This means that employee performance variables that can be explained by communication, work environment and work discipline variables are $21.7 \%$ while the remaining $78.3 \%$ of other variables cannot be explained in this study.

\section{REFERENCES}

Alex, S.N. (2005). Personnel Management (Human Resource Management). Fourteenth Printing. Jakarta: Ghalia.

Arikunto, S (2010). Research Procedure of Practical Approach. Jakarta: Rineka Cipta.

Bangun, W. (2012). Human Resource Management. Jakarta: PT Gelora Aksara Pratama.

Ghozali, I. (2013). Application of Multivariate Analysis with SPSS Program. Semarang: Research Agency of UNDIP.

Gunaseelan. (2016). A Study on The Impact of Work Environment on Employee Performance. International Journal of Science and Research (IJSR), 3(1).

Handoko, T.H. (2011). Personnel Management and Human Resources Second Edition. Eighteenth Printing. Yogyakarta: BPFE Publisher.

Harun, R. (2008). Organizational Communication. Bandung: CV. Mandar Maju.

Hasibuan, M. (2002). Human Resource

Management. Jakarta: Bumi Aksara.

Hustin, et al. (2013). The Effect of Communication, Leadership and Work Motivation on Employee Performance: A Study at Regional 
Office XII Directorate General of State Assets (DJKN) Banjarmasin. Journal of Management Insights, 1(2).

Iskandar. (2017). Effect of Individual Characteristics, Workload and Work Environment on Employee Performance at the Inspectorate Office of Central Sulawesi Province. e-Journal Catalog, 5(1), 67-79.

Kasiram, M. (2008).

Research Methodology. Malang: UIN-Malang Pers.

Mangkunegara, et al. (2015). Effect of Training, Competence and Discipline on Employee Performance in Company (Case study in PT. Asuransi Bangun Askrisda. Proceeding of Second Conference on Business and Social Science 2015 Bali Indonesia.

Marwansyah. (2010). Human Resource Management. Bandung: Afabeta.

Parerung, et al. (2014). Discipline, Compensation and Career Development Impacts on Employee Performance at the Environmental Agency of North Sulawesi Province. EMBA Journal, 2(4), 688-696.

Peoni. (2014). Influence of environmental and individual characteristicActivity to performance employees (A Study at PT. Taspen Persero Branch Manado). Journal of Universitas Sam Ratulangi 2014.

Prasetya, et al. (2014). Effect of Work Environment on Employee Performance (A Study on Employees of North Malang Pratama Tax Office). Business Administration Journal (JAB), 8(2).

Rivai, V. (2011). Human Resource Management For Companies From Theory Into Practice. Jakarta: Raja.

Sedarmayanti. (2011). Human Resources and Work Productivity. Bandung: Mandar Maju.

Setiawan, J. (2013). Effect of Individual Characteristics and Work Environment on Employee
Performance at PT.Awetama Bina Reksa. AKMENBIS Journal of Permata Harapan Academy of Accounting, 2(1), 55-70.

Srimiatun, T.P. (2017). Effects of Communication and Conflict on Employee Performance of State Polytechnic Education Personnel. Madiun Epicheirisi, 1(1).

Suci., \& Idrus. (2015). The Influence of Employee Training and Discipline Work Againts Employee Performance PT. Merpati Nusantara Airlines (Persero). Review of European Studies, 7(11).

Sugiyono. (2016). Educational Research Methods (Quantitative Approach, Qualitative and R\&D. Bandung: Alfabeta.

Sujarweni, V.W. (2015). Statistics for Business and Economics. Yogyakarta: Pustaka Baru Press.

Suliyanto. (2006). Business Research Methods. Yogyakarta: Andi.

Suliyanto. (2011). Applied Econometrics: Theory \& Application with SPSS. CV. Andi Offset.

Sumaki, et al. (2015). The Effects of work discipline, organizational culture and communication on employee performance at PT. PLN (Limited) in the Region of Suluttenggo Manado. Periodical Journal of Scientific Efficiency, 15(5).

Susanto. (2013). Effects of Communication, Leadership and Work Motivation on Employee Performance. A Study at Regional Office XI Directorate General of State Assets (DJKN) Banjarmasin. Journal of Management Insights, 1(2).

Taufiq, et al. (2012). Effects of Work Environment and Work Discipline and Work Motivation on the Performance of Employees of Lumajang Regional Water Supply Company (PDAM). Journal of WIGA, 2(1). 
Thaief, et al. (2015). Effect of Training, Compensation and Work Discipline againstEmployee Job Performance (Studies in the Office of PT. PLN (Persero) Service Area and Network Malang). Review of European Studies, $7(11)$.

Wardhani. (2016). The Effects of Work Environment, Communication and Leadership on Employee Performance (A Case Study in Culture and Tourism Office of Semarang). Journal of Management, 2(2).

Windy J.S. (2015). The Effect of Work Discipline, Organizational Culture, and Communication on the Performance of Employees of PT.
PLN (Limited) in the Region of Suluttenggo of Manado. Journal of Scientific Periodic Efficiency, 15(5). 